\title{
RELIQUIAE DILUVIANAE ALTER: LAST INTERGLACIAL FLOOD DEPOSITS IN THE CAVES OF THE WEST INDIES
}

\author{
Donald A. McFarlane, and Joyce Lundberg*
}

\section{ABSTRACT}

Recent efforts to extend the terrestrial vertebrate record of the West Indies have resulted in the discovery of distinctive last-interglacial (Sangamonian) cave deposits on the islands of Jamaica, Puerto Rico, Hispaniola, and Anguilla. Each of these deposits apparently represents debris (including vertebrate bone) emplaced by catastrophic flooding during last-interglacial time. These are currently the only dated West Indian Late Quaternary vertebrate fossil-bearing cave deposits that are older than late Pleistocene (i.e., older than $35 \mathrm{ka}$ ). Moreover, no site from the time interval $35-100 \mathrm{ka}$ has been found, suggesting that the conditions which resulted in the formation of these flood deposits have been rare or absent in post-Sangamonian time. We interpret this pattern as indicative of an episode of severe climate (perhaps increased hurricane frequency or severity) that may have occurred during oxygen isotope stage $5 \mathrm{e}$.

\section{INTRODUCTION}

Vertebrate paleontological remains in caves have long been recognized as a vital and insightful source of paleoenvironmental information; as early as 1823, Buckland produced the beautifully illustrated volume Reliquiae Diluvianae documenting many cave paleontological sites in Europe as evidence of a paleo-flood, in this case interpreted as the biblical flood. In tropical environments, caves are often the only terrestrial environments in which vertebrate remains are commonly preserved, save for unusual exceptions such as the famed Dominican amber deposits (Poinar and Cannatella, 1987), and asphalt seeps in Trinidad and Cuba (Akersten, 1980). In the West Indies, the presence of a largely -exterminated and very unusual Late Quaternary mammalian fauna has inspired a 130-year history of paleontological investigation in the abundant karst of these islands. The earliest efforts by E. D. Cope in the late $19^{\text {th }}$ century (based on field collections by van Rijgersma; McFarlane and MacPhee, 1989; 1993) led to early speculation concerning sea-level and sundered land bridges, and is embodied in Copes specific epithet for the giant extinct rodent of Anguilla, Amblyrhiza inundata. More than a century later, patterns of West Indian fossil vertebrate distributions were used to infer an episode of late Pleistocene aridity (Pregill and Olson, 1981).

In view of the fact that paleoclimatic interpretations of the fossil record must depend on a good radiometric framework, it is surprising that radiometric studies of the

\footnotetext{
* Donald A. McFarlane, W. M. Keck Science Center, Claremont,CA 91711, USA. Joyce Lundberg, Dept. of Geography and Environmental Studies, Carleton University, Ottawa, K1S 5B6, Canada.
} 


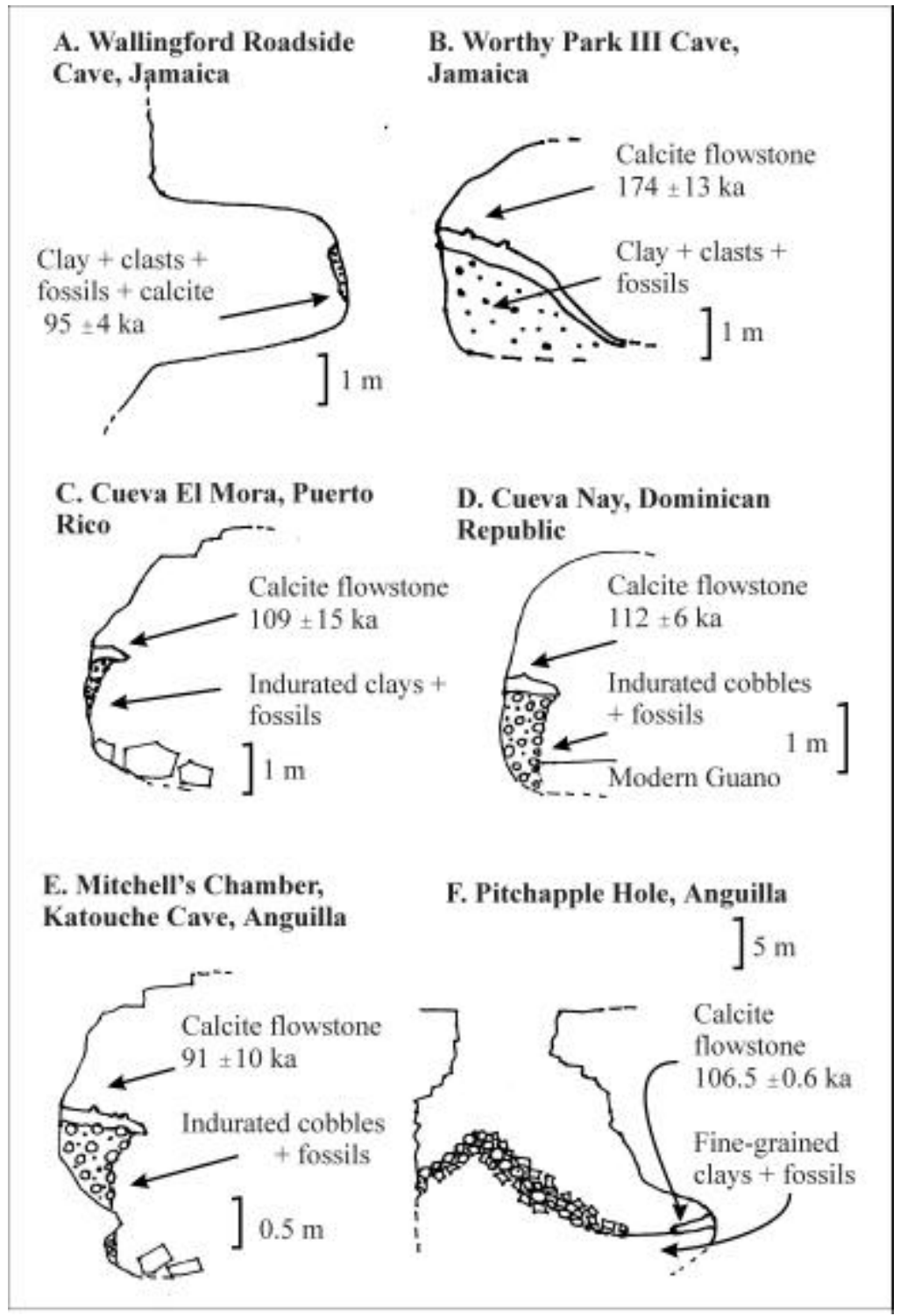

Figure 1. Diagrammatic cross sections of flood deposit sites.

West Indian vertebrate record were slow to begin. As late as 1981, only a single radiometrically-supported study was in print (Pregill, 1981). In the late 1980s this began to change, and there are now more than 60 published radiometric dates on late Quaternary West Indian vertebrates or vertebrate-bearing sites. 
The West Indian terrestrial mammal fauna has had a long tenure on the islands, which is reflected in its high degree of phylogenetic distinctiveness. The earliest known mammalian specimen is from Eocene lagoonal deposits of Jamaica (Domming et al., 1997). However, the bulk of the mammalian record is preserved in cave deposits which do not extend back to such times because caves are relatively ephemeral over geological timescales. The oldest West Indian cave vertebrate-bearing deposits currently known are clastic dikes exposed in Cueva del Aleman, Isla de Mona, that have been dated to the earliest Pleistocene by paleomagnetic methods (Panuska et al., 1998).

Here we present a new synthesis of scattered paleontological data from the West Indies dating from the Late Quaternary, in particular, marine isotope stage (MIS) 5, and an interpretation of the paleoenvironmental significance of their temporal distribution and of the characteristics of the sediments in which they occur.

\section{RESULTS}

\subsection{Last Interglacial Paleontological Records From West Indies Cave Deposits}

Only a few sites in the West Indies have been found with paleontological remains from the Last Interglacial. These include sites from Jamaica, Puerto Rico, Dominican Republic, Jamaica, and Anguilla. The dates discussed below are all UTh dates (the raw data are already published in the relevant publications). In this discussion, all errors are $1 \sigma$.

The first of the West Indian Last Interglacial cave sites to be identified was Wallingford Roadside Cave, Jamaica (Fig 1a). It contains a 'bone breccia' consisting of a vuggy clay indurated with calcite stringers and containing abundant vertebrate remains and a few small clasts. The extinct rodent(s) Clidomys, together with turtle and crocodile remains have been recovered. A suite of U/Th dates provide an age of $95 \pm 4 \mathrm{ka}$ for the calcite indurations and a maximum age of 130-180 ka for the fossils (MacPhee et al., 1989) placing them within MIS 5, the Last Interglacial.

Worthy Park I Cave, Jamaica (Fig 1b), is very similar to Wallingford Roadside Cave. The fossil-bearing deposit is an indurated clay plastered onto the walls of the entrance chamber, containing bones of Clidomys together with remains of freshwater turtle and frogs. The deposit is partially overlain with a flowstone that has yielded a U/Th age of $174+13,-12 \mathrm{ka}$, which places it in marine isotope stage 6 (McFarlane et al., 1998).

The site from Puerto Rico, Cueva El Mora (Fig 1c), consists of remnants of a cave clay with clasts and bones of the extinct rodent Elasmodontomys, indurated and capped with flowstone. A U/Th date on the flowstone capping yielded an age of 108.9 $+15.4,-13.3 \mathrm{ka}$, again placing the fossiliferous deposit most likely within MIS 5 (McFarlane et al., in press).

The Cueva Nay site, Dominican Republic (Fig 1d), is an abandoned trunk passage which preserves an incised bank of indurated stream cobbles, containing sparse vertebrate remains of the ground sloth cf. Parocnus, and capped with flowstone. A U/Th date on this flowstone gave an age of $112 \pm 6 \mathrm{kyr}$ BP (McFarlane et al, 2000).

Mitchell's Chamber, in Katouche Cave, Anguilla, is a remnant of an abandoned cave stream passage with a thick deposit of stream gravels and cobbles (Fig 1e). This deposit preserves remains of the giant rodent, A. inundata. The whole deposit is capped 
with flowstone and penetrated by calcite stringers. Multiple dates on this flowstone and calcite are statistically indistinguishable at $91 \pm 10 \mathrm{ka}$ (McFarlane et al., 1998). The stream deposits and associated fossils must thus have been emplaced before the end of marine isotope stage 5, and most likely within the Last Interglacial. For various reasons, discussed in McFarlane et al. (1998), A. inundata is believed to have become extinct during the last interglacial.

Pitchapple Hole, in Anguilla, is a $20 \mathrm{~m}$ deep, open pit cave (Fig 1f) which contains an accumulation of lateritic cave earth containing abundant remains of $A$. inundata. A minimum age for the fossiliferous deposit of $106.5 \pm 0.6 \mathrm{kyr}$ BP was

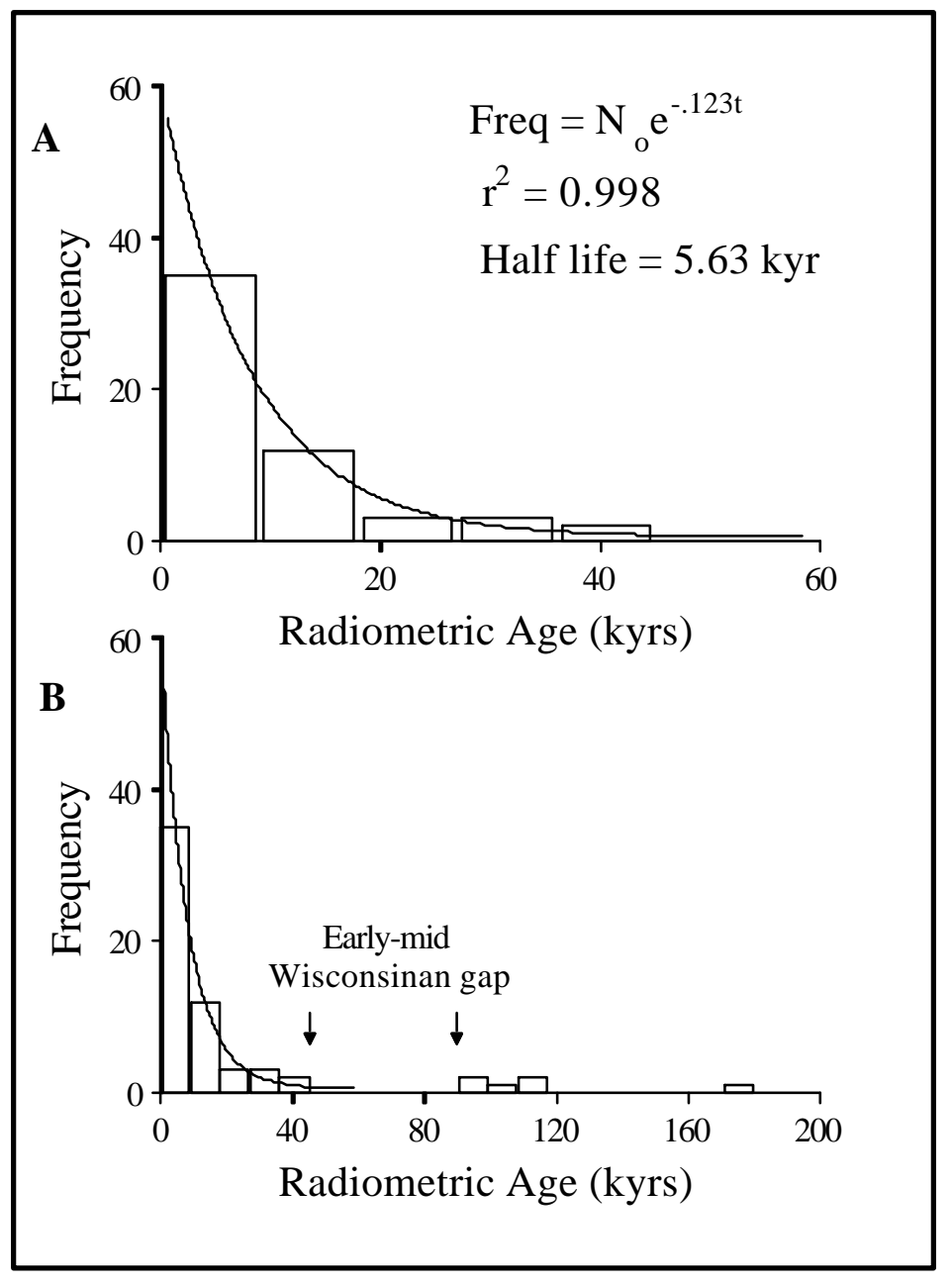

Figure 2. A: Age distribution of West Indian vertebrate sites over the past 50,000 years. B: Age distribution of all Quaternary West Indian vertebrate sites. 
obtained by U/Th dating of an overlying flowstone shelf (McFarlane et al., 1998). Specimens of Amblyrhiza occur to within a few centimeters of the surface of the cave earth, indicating that little if any sediment accumulation has occurred here since Last Interglacial time.

All these sites, except for the Worthy Park site, date to MIS 5, the Sangamonian Interglacial. The distribution of these ages is discussed below as part of a general model of fossil distribution patterns.

\subsection{Temporal distribution of paleontological data from West Indies}

Caves are often relatively short-lived phenomena on geological timescales, and fossil-bearing deposits even more so as they are eroded away or rendered inaccessible (and hence undiscovered) by collapse or infilling. Because these processes are either progressive (erosion) or essentially random (collapse), the probability of a fossil-bearing deposit surviving decreases with its age. If the probability of a fossil-bearing deposit being lost is approximately constant through time, then the age-frequency distribution of surviving deposits should show exponential decay. Taking all of the published West Indian radiocarbon data and plotting them against time (Fig $2 \mathrm{~A}, \mathrm{n}=55$ ) shows that they fit this pattern throughout the last 50,000 years. The approximate 'half-life' of the exponential decay curve is $\sim 6{ }^{14} \mathrm{C} \mathrm{kyr}$. This therefore confirms the hypothesis of exponentially decreasing probability of preservation; the implication of this model is that the expected number of fossils for any age can be predicted.

However, if the six dates discussed above are added to the data set (making up the total published radiometric dataset for West Indian Late Quaternary vertebrate fossils) the graph (Fig 2B) reveals a somewhat different pattern. Five of the dates are centered on, or overlap, the last interglacial (Sangamonian), and one pre-dates it. Each of these dates was the result of attempts to interpret interesting paleontological assemblages irrespective of age, and are not artifacts of special efforts to locate old deposits. If the half-life for West Indian cave vertebrate sites in the Late Quaternary is $\sim 6{ }^{14} \mathrm{C} \mathrm{kyr}$, and if one assumes a constant probability of deposition and/or preservation, then the probability of finding 5 of 61 dates dating from the Last Interglacial is vanishingly small ( $p<10^{-6}$ ). Clearly, we can have a high degree of statistical confidence in concluding that the probability of deposition and/or preservation has not been constant throughout the past $200 \mathrm{kyr}$, but in fact was many times higher during the Last Interglacial than at any time in the succeeding Wisconsinan.

\subsection{Characteristics of sediments}

The second feature of interest in these six sites is the nature of the deposits in which the fossils are found.

The Wallingford Roadside Cave and the Worthy Park sediments are calcitecapped fluvial remnants, in the case of Wallingford plastered against the walls of the caves, and in the case of Worthy Park forming a sediment bank at the side of the passage. They have no signs of stratification. The sediments contain rounded clasts $1-2 \mathrm{~cm}$ in diameter. The Hjullstrom diagram of flow velocity required to entrain and transport clastic grains indicates water velocities of 1 to $1.5 \mathrm{~ms}^{-1}$. The sediments are poorly packed, 
with many gaps between clasts, as if rapidly deposited, perhaps with organic debris that has now decayed. The nature of some of the fossil re mains (turtle, frog, and crocodile) suggests transportation by river flow rather than by vectors such as owls. Both of the Jamaican caves are in a similar situation; both today have large modern rivers sinking into base of a cliff. The caves, now $~ 40$ meters above the modern river level, represent former sinks and are now closed or almost closed off with cave fill (McFarlane and Gledhill, 1985). The active cave walls are completely clean of sediment. The preservation of the sediment on the sides of the higher level caves implies no significant flood since emplacement. They may have been put in place during a very high water level event long after the abandonment of the passage as the normal sink.

The sediments in Cueva El Mora are as much as $3 \mathrm{~m}$ above the modern floor, and consist of clay with clasts and fossils but again with no indication of stratification. The clasts, of the order of $1-2 \mathrm{~cm}$ in diameter, are rounded to sub-rounded cobbles. The clay is also is full of holes, and contains turtle plastron fragments. The sediment beside the wall is somewhat indurated and has remained in place while the rest of the floor has since been removed. Stream flow is presumed to occur during extreme events such as hurricanes but no flow is observed in the cave today and no stream deposits have been emplaced since this Last Interglacial remnant.

The Cueva Nay sediments are in a very similar situation, although the clasts, at $5-10 \mathrm{~cm}$ diameter, are larger and the indurated sediment now plastered to the wall has less clay. These cobbles look like typical coarse-grained, bed-load alluvial deposits (but with no stratification) and suggest velocities of $\sim 2-3 \mathrm{~ms}^{-1}$. However, the presence of sloth vertebrae with undamaged vertebral processes suggest that the clasts were not transported for long distances during the particular episode that emplaced this deposit. The rounded allogenic clasts (many of volcanic lithologies) probably attained their roundness outside of the cave. The cave is situated east of a large intermittently-flooded polje whose only drainage is via another cave hydrologically connected to Cueva Nay (but now blocked). It is likely that the rounded clasts and the sloth bones were carried in from polje in a brief, high energy event.

The deposit in Mitchell's Chamber consists of sub-rounded gravel and cobbles (Fig 3). They range in size from 2 to $15 \mathrm{~cm}$ in longest axis and again look like standard bed-load deposits and indicate water velocities of $\sim 3.5 \mathrm{~ms}^{-1}$. They are clearly distinct from the other sediments in the cave, which are generally rare, and consist of fine-grained muds deposited in standing water, typical slack-water deposits. There appear to be no active stream deposits today, flow has not been observed in the cave, and, indeed, no surface streams are known on Anguilla. The Mitchell's Chamber deposit has been exposed by intermittent stream erosion and Katouche cave therefore presumably still carries an intermittent stream during extreme wet weather, but none of these flows have been energetic enough to have flushed significant surface debris, clasts, or vertebrate remains into the cave and the stream passage has not accumulated any kind of comparable clastic deposit since Last-Interglacial time. The flowstone capping is also distinct in that no other flowstone of comparable thickness occurs anywhere else in the cave; the rare, modern calcite deposits are in the form of thin and broken films. 


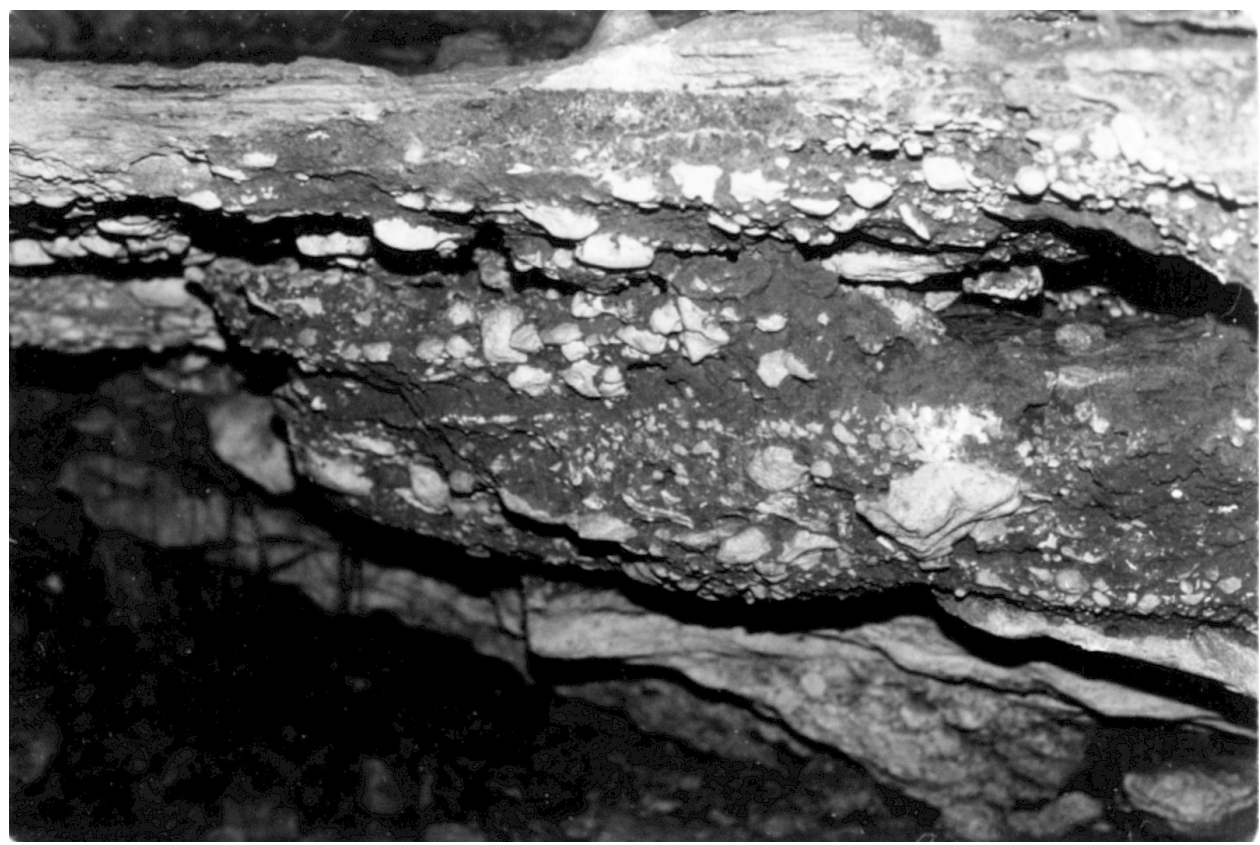

Figure 3: Gravel and cobble sediment capped by calcite flowstone, in Mitchell's Chamber, Katouche Cave, Anguilla

The fossil-bearing sediments in Pitchapple Hole are somewhat different from the other five deposits in that they are not obvious stream deposits. The sediments consist of fine-grained red clays accumulated at the foot of the breakdown talus filling the center of the pit. It is likely that they represent the flushing of fines out of the talus, but they have no evidence of any kind of stratification, no hardgrounds, no lenses of coarse-grained lags or anything that might suggest accumulation over a long time period. The feature that cannot easily be explained by slow flushing out of fines over time is the size of the vertebrate remains that are distributed throughout the red clay. These range up to $10 \mathrm{~cm}$ in longest dimension (Fig. 4). The standard Hjullstrom diagram is not designed for nonrock clasts and so cannot be used to indicate probable flow velocities; it can only be noted that the flow required to carry these bones must have been of sufficient velocity and discharge to entrain and transport relatively large clasts. Sedimentation stopped at the end of the Last Interglacial with the calcite capping. No comparable deposit from any more recent age can be found in the cave, and once again, stream flow is never observed in this cave or on the surface today.

\section{PALEOENVIRONMENTAL INTERPRETATION}

These six sites have several distinct features that must be explained: the unusual nature of the fossil assemblage; the unusual nature of the sediments; and the unexpectedly high rate of preservation. 


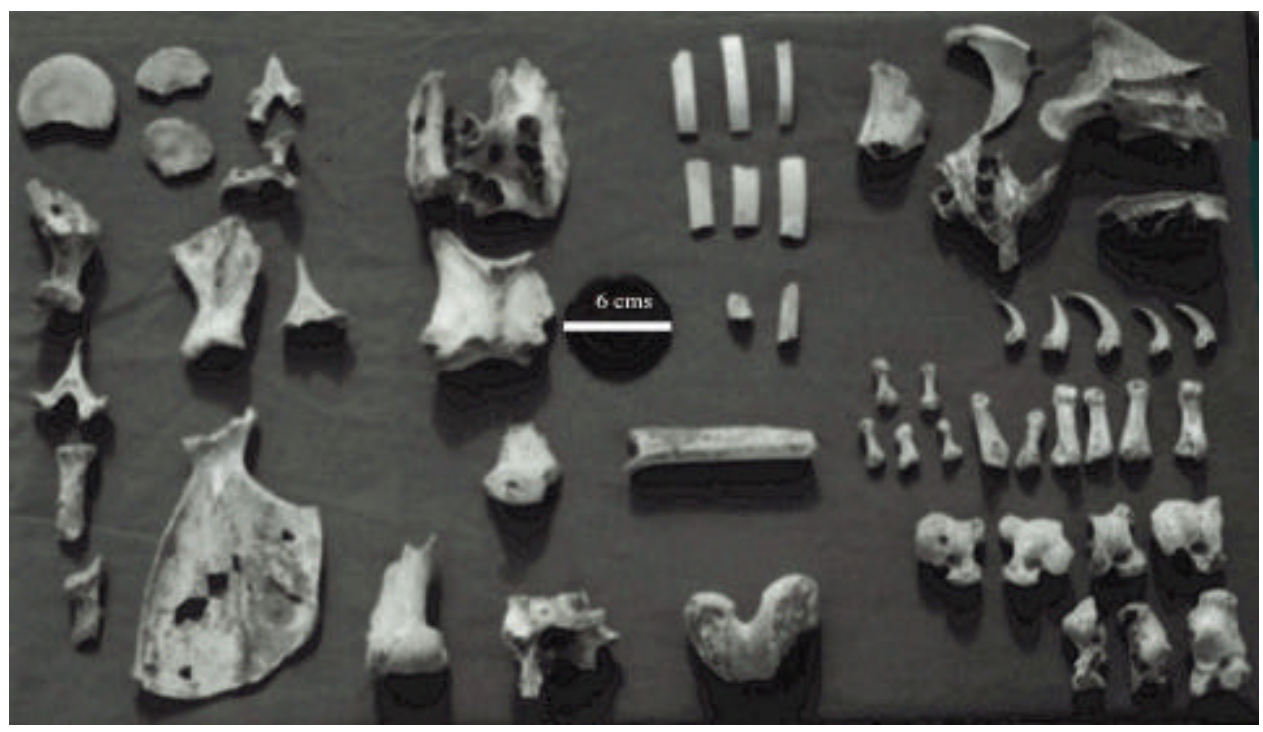

Figure 4. Amblyrhiza bone remains from Pitchapple Hole, Anguilla.

\subsection{The unusual nature of the fossil assemblage}

Vertebrate bone deposits accumulate in West Indian caves through several distinct processes. Most commonly, rich deposits of small vertebrates accumulate below owl roosts. These deposits are readily recognized by their lack of vertebrates with living body masses greater than 1-2 kgs, and by their high proportion of bird remains. Vertebrates also accumulate in caves through accidental falls into pits. These deposits over-represent larger vertebrates, and are deficient in birds and small reptiles.

The six sites lack either of these signatures, suggesting an alternative mode of transportation and deposition. Each of the known Last Interglacial vertebrate cave sites, with the exception of Pitchapple Hole, Anguilla (a pit-fall site), exhibits a taphonomy best interpreted as the result of storm-emplacement. We interpret each of these deposits as death assemblages emplaced by major floods backing up from the local river or stream sink, Wallingford Roadside cave, Jamaica, being a classic example where the fossil deposits are emplaced in a cave $40 \mathrm{~m}$ above the modern river sink

\subsection{The unusual nature of the sediments}

The six deposits have many characteristics in common. The fossil remains include a mixture of large and small mammals, small birds, small reptiles, and aquatic vertebrates. The bones and teeth of megavertebrates deposited amongst stream cobbles are relatively unworn, suggesting little transportation. Most of the sediments are an inhomogeneous mixture of large and small vertebrate remains, stream cobbles, clays, and cavities. None are stratified and yet all seem to be fluvial deposits. Most are poorly 
packed with inter-clast cavities. Most have relatively big clasts but at the same time preserve fossil remnants in a comparatively undamaged state. All are distinct from any subsequent deposits. All seem to have been deposited within a fairly short time interval and are not complicated by any subsequent deposition. Taking all this evidence together the most parsimonious explanation we have is that the sediments represent catastrophically emplaced flood deposits.

\subsection{The unexpectedly high rate of preservation}

The unusually high number of preserved MIS 5 sites (several orders of magnitude higher than expected) requires unusual conditions of preservation. In view of the fossil assemblage and the nature of the sediments we suggest that the catas trophic floods created extraordinary conditions for preservation of fossil remains and that they have not been destroyed because no comparable floods have occurred since last interglacial times in these caves.

\section{DISCUSSION}

We suggest that the evidence indicates that the last interglacial may have experienced extreme, although probably rare, flood events. Given that similar cave deposits are not known from the West Indian Wisconsinan or Holocene record, we interpret this to mean that the West Indies were subject to more intense storm activity during the Last Interglacial.

If our interpretation is correct, we would expect to find other evidence of enhanced storm or hurricane activity in the geological record of the West Indies. While there are no other published records of storm events at inland sites, there is some evidence of increased wave activity on coastal sites, presumably indicating enhanced storm activity. Hearty et al. (1998) interpret a series of coastal sand ridges on the windward margin of several of the Bahama Islands as originating from extreme storms during the last interglacial. 'Megaboulder' (boulders of $\sim 10^{6} \mathrm{~kg}$ ) deposits on Eleuthra (Hearty, 1997), suggest unusually intense wave activity at some stage during the last interglacial, which has been attributed to tsunamis or extreme hurricanes.

In view of these rather limited examples it seems that the evidence for catastrophic storms in the West Indies during MIS 5 is not yet very well supported. However, evidence for MIS 5 climatic instability in global climatic proxies such as ice and ocean cores is quite common (although currently under review, c.f. Kukla 2000). Adkins et al 1997 observe a rapid shift in oceanic circulation patterns around $118 \mathrm{ka}$, although their impact on storm patterns is unresolved. Ice cores show evidence of the strikingly difference nature of the Holocene and the Sangamonian Interglacials. For example, the GRIP ice core shows the Holocene as relatively stable but the Sangamon as fluctuating (Dansgaard et al., 1993).

In conclusion, the existence of karst 'hyper-flood' sedimentary facies in the last interglacial cave deposits of at least four West Indian islands suggests that additional efforts should be made to identify the signature of extreme events in MIS 5e deposits elsewhere in the Caribbean 


\section{REFERENCES}

Adkins, J. F., E. A. Boyle, L. Keigwin, and E. Cortijo. 1997. Variability of the North Atlantic thermohaline circulation during the last interglacial period. Nature 390: 154-156.

Akersten, W. A. 1980. Fossils in asphalt. Science 248: 552.

Buckland, W. 1823. Reliquiae Diluvianae; or, observations on the organic remains contained in caves, fissures, and diluvial gravel, and on other geological phenomena, attesting to the action of an universal delu ge. Murray, London.

Dansgaard, W., S. J. Johnsen, H. B. Clausen, D. DahtJensen, N. S. Gundestrup, C. U. Hammer, C. S. Hvidberg, J. P. Steffensen, A. E. Sveinbjornsdottir, J. Jouzel, and G. Bond. 1993. Evidence for general instability of past climate from a 250-kyr ice-core record. Nature 364: 218-220.

Domning, D. P., R. J. Emry, R. W. Portell, S. K. Donovan, and K. S. Schindler. 1997. Oldest West Indian land mammal: rhinocerotoid ungulate from the Eocene of Jamaica. Journal of Vertebrate Paleontology 17: 638-641.

Hearty, P. J. 1997. Boulder deposits from large waves during the Last Interglaciation at North Eleuthera, Bahamas. Quaternary Research 48: 326-338.

Hearty, P. J., A. C. Neumann, and D. S. Kaufman. 1998. Chevron ridges and runup deposits in the Bahamas from storms late in oxygen-isotope substage 5e. Quaternary Research 50: 309-322.

Kukla, G. J. 2000. The Last Interglacial. Science 287: 987-988.

MacPhee, R. D. E., D. C. Ford, and D. A. McFarlane. 1989. Pre-Wisconsinan mammals from Jamaica and models of late Quaternary extinction in the Greater Antilles. Quaternary Research31: 94-106.

McFarlane, D. A., and R. E. Gledhill. 1985. The Quaternary bone caves at Wallingford, Jamaica. Cave Science 12: $127-128$.

McFarlane, D. A., J. Lundberg, A. Vale, and S. E. Lauritzen. in press. New specimens of the giant extinct rodent Elasmodontomys obliquus (Rodentia; Heptaxodontidae) from Puerto Rico, West Indies. Caribbean Journal of Science.

McFarlane, D. A., and R. D. E. MacPhee. 1989. Amblyrhiza and the Quaternary bone caves of Anguilla, British West Indies. Cave Science 16: 31-34.

-. 1993. Amblyrhiza and the vertebrate paleontology of Anguillan caves. Boletin de la Sociedad Venezolana de Espeleologia 27: 33-38.

McFarlane, D. A., R. D. E. MacPhee, and D. C. Ford. 1998. Body size variability and a Sangamonian extinction model for Amblyrhiza, a West Indian megafuanal rodent. Quaternary Research 50: 80-89.

McFarlane, D. A., A. Vale, K. Christenson, J. Lundberg, G. Atilles, and S. E. Lauritzen. 2000. New specimens of Late Quaternary extinct mammals from caves in Sanchez Ramirez Province, Dominican Republic. Caribbean Journal of Science 36: 163-166.

Panuska, B. C., J. M. Mylroie, D. Armentrout, and D. McFarlane. 1998. Magnetostratigraphy of Cueva del Aleman, Isla de Mona, Puerto Rico and the species duration of Audubon's Shearwater. Journal of Cave and Karst Studies 60: 96-100.

Poinar, G. O., and D. C. Cannatella. 1987. An upper Eocene frog from the Dominican Republic and its implication for Caribbean biogeography. Science 237: 1215-1216.

Pregill, G. K. 1981. Late Pleistocene herpetofaunas from Puerto Rico. Miscellaneous Publications, University of Kansas Museum of Natural History 71: 1-72.

Pregill, G. K., and S. L. Olson. 1981. Zoogeography of West Indian vertebrates in relation to Pleistocene climatic cycles. Annual Rev. Ecol. Syst. 12:75-98. Annual Review of Ecology and Systematics 12: 75-98. 